\title{
Developing A Digital Repository Based on Educational and Technical Standards to Provide Interactive E-Learning Content for Post-Basic Education Students in Oman
}

\author{
Authors \\ Dr. Walid Aboraya ${ }^{1}$, Dr. Nader Shemy ${ }^{2}$, Dr. Sameh Said $^{3}$, Dr. Muna Alkalbani ${ }^{4}$, Naglaa \\ Shehata $^{5}$, Baraa Abdelhady ${ }^{6}$
}

\begin{abstract}
Digital repository is defined as a set of interrelated electronic documents, stored in files or a database, usually classified in categories, that stores knowledge useful to an enterprise or other organization. The current study aimed to develop a digital repository for learning objects based on the educational and technical standards, in order to provide interactive e-learning content for postbasic education students in educational institutions in the Sultanate of Oman. The repository was developed in light of international technical and educational standards and the potential of the Omani educational community. Then it was made available to a sample of one hundred Omani teachers randomly selected from post-basic Omani schools to determine the ease of access, use, and effectiveness from their perspective through applying a questionnaire. The study sample represented different disciplines, years of experiences, and both genders. The questionnaire comprised seventeen statements reflecting the research aims and were built based on the literature. Validity and reliability were checked before administering the survey. The results showed that most teachers $(87 \%)$ were satisfied with using the repository in terms of ease of use, accessibility, and effectiveness. This informs that teachers are in dire need for using a customized digital repository for Omani curriculum and they are ready to use it.
\end{abstract}

Keywords: Digital Repository, Interactive E-Learning Content, Post-Basic Education. Learning Objects

${ }^{1}$ Main Researcher, Arab Open University, Oman

${ }^{2}$ Arab Open University, Oman

${ }^{3}$ Sultan Qaboos University, Oman

${ }^{4}$ Ministry of Education, Oman

${ }^{5}$ Helwan University, Egypt

${ }^{6}$ Dar Al-Fatwa, Egypt 


\section{Developing A Digital Repository Based on Educational and Technical Standards to Provide Interactive E-Learning Content for Post-Basic Education Students in Oman}

\section{Introduction}

Online learning has become popular because of its potential for providing more flexible access to content and instruction at any time, and anywhere. There are many definitions for the concept of E-learning, one of its definitions is According to (Alanazi \& Abbod, 2014) "the use of new multimedia technologies and the internet to improve the quality of learning by facilitating access to resources and services".

Among the tools used in online learning are digital repositories. A digital repository is a computer application that allows you to store information and offers different services to the user. Essentially it allows searching and retrieving stored information. It is the provision of individualized, informative, dynamic content of learning in real time, helping to grow awareness groups, connecting learners and practitioners with specialists. (Castro, 2021), (Nyakurerwa, 2021)

Digital repository is a term given to a kind of instruction and learning system in which the students and the teacher, or whoever is involved in the interchange of information, do not meet physically, but rather are separated by time, distance, or both. This separation is bridged with the help of communication technology, including the Internet and emergent educational technologies. (Alkhalaf, Drew, and Alhussain, 2012)

The perfect IT solution used to digitally store, process, and retrieve didactic content is a digital repository of educational materials. Repositories can be made in various 
المجلد الخامس (العدد السادس)

2021
المجلة الدولية للمناهج و التربية التكنولوجية

IJCTE

forms, subject to materials, technological infrastructure, usability, user habits, and IT capabilities. A basic solution for digital file storage can be called a didactic content repository. A dedicated IT system that needs materials structured according to a defined technical requirement may also be regarded as a repository. The type of technical solution used to establish a repository is connected to the technical standard for recording teaching materials, and to their role in the process of distance learning. (Marciniak, 2014 ),( Bogucki, 2021)

The problem of most e-learning systems occurs in the absence of a unified model that focuses on educational and technological standards in the design and manufacture of digital learning components, or in the absence of a consistent access and usage process in order to make them accessible to the targeted students.

In every educational community, the problem of accessibility steadily escalates, particularly if the information stock in this community is increasing, because it has a duty to make that knowledge accessible to the recipients of this community in all its forms, without restrictions or conditions. And this is what this study presents and relates to post-basic education in the Sultanate of Oman, based on the assumption that the presence of digital repositories can lead to easy access to the available knowledge and may be the most popular and common method.

The digital repository is a mechanism for every information society that gathers, maintains, manages, and provides access to intellectual property items. Text, audio, video, and multimedia materials may be part of intellectual products and may also be interactive content. These repositories help to provide every intellectual / educational group with many value-added advantages. 
Digital repositories with e-learning content contribute to providing many valueadded benefits to any intellectual / educational community, and the most important of these advantages are:

- Making digital content available to the largest segment of beneficiaries without any restrictions.

- Encouraging the concept of knowledge sharing among the members of any intellectual/ educational community.

- Establishing the idea of pluralism and diversity in the targeted knowledge sources.

- Preserving the intellectual property of the owners of the knowledge resources and encouraging them to have more participation.

- Overcoming spatial and temporal obstacles and barriers to access knowledge.

- Accessing to renewable and modern resources in all scientific disciplines.

- Preserving the intellectual / cognitive production and the ease of reference and access to it at any time and from anywhere.

- Ease of publishing and digital availability of any intellectual productions without being bound by the traditional (printed) method of publishing.

In light of the previous advantages of digital repositories, and in the context of the global consensus on the existence of these warehouses in all educational institutions of various educational levels, and in light of the severe and increasing need for digital educational content for the post-basic education stage in educational institutions in the Sultanate of Oman, the researchers focused on the necessity of researching the extent of designing and developing a digital repository that contains the knowledge and educational production related to the study materials at that educational stage, 
المجلد الخامس (العدد السادس)

2021
المجلة الدولية للمناهج و التربية التكنولوجية

IJCTE

this content is designed based on the concept of learning objects that present the content in an integrated and stand-alone manner (multimedia, activities, exercises, continuous self-evaluation, and other elements).

\section{Literature Review}

Digital repositories improve access to online education and training, improve the quality of teaching and learning, and are needed for educational institutions to maintain a competitive advantage in this changing student market (Luaran et al., 2014 and Starzyńska \& Klembalska, 2021). This has led to the full exploitation of information technology in improving the teaching and learning process in the different stages of education, and at the same time providing educational programs to a larger number of students in an easy and distinct way. This means that digital repositories can enhance the quality of teaching and learning.

Many researchers have described the importance of e-learning for students as well as the design of digital learning repository models. Among those studies are Luaran (2014) who aimed to investigate the effectiveness of using e-learning materials among secondary school students. Data were collected from 45 students studying at three schools in Shah Alam, Selangor. Results showed that most of the respondents were exposed to e-learning and among the reasons why they preferred to learn via e-Learning was that it provided them with greater flexibility to select either instructor-led or self-study courses and enabled them the flexibility to learn at any place and time. They also agreed that one of the disadvantages of using e-Learning was that it would reduce the need for face-to-face interaction with their friends.

Alkhalaf (2012) also presented results from a study of the effects of e-learning systems on university students in the Kingdom of Saudi Arabia. It is asserted that 
the calculation of the effect on learners of e-learning systems is fundamental to the creation of relevant and efficient frameworks of e-learning. In order to capture their impressions of their existing e-learning programs, students from two separate universities in the KSA were surveyed. The evaluation framework is based on the Success/Impact Measurement framework (SIM), which has been successfully applied to similar studies on e-learning, e-health, and e-government.

Sek et. al (2012) aimed to reveal the effectiveness of the learning aspects in the course on digital systems, and the findings of the study showed that there were statistically significant differences in performance and achievement for the benefit of students who studied using the learning elements.

Also, Ozdemir \& Bonk (2017) presented an exploratory analysis to identify teachers' knowledge of open-source educational materials (OER) in pre-university education. In order to identify their views of the idea of open-source educational materials, the possibilities for their use, and the difficulties they may face in educational institutions, data is collected from 99 teachers. The study concluded that there are some barriers associated with the collection, modification, and implementation of educational materials from open source and recommended to develop digital repositories for pre-university education due to their potential effect on improving students' performance.

Morales et al. (2017) established a model for a digital learning resources repository in a manner that promotes access to learning resources and adapts to the needs and desires of students. Also, Zervas et. al. (2016) established a model for a metadata schema that represents the digital repositories' learning tools. This model was created to help teachers of science, technology, engineering, and mathematics in (STEM) 
المجلد الخامس (العدد السادس)

2021
المجلة الدولية للمناهج و التربية التكنولوجية

IJCTE

schools in order to share their lesson plans. The model also provided the teachers with accessible and effective educational resources as described by them.

Marciniak (2014) presented the method and tools to create digitalized didactic content repositories to facilitate their reusability. The approach consisted of a collection of recommendations for the structuring of didactic materials and a way through the UCTS (i.e., Universal Curricular Taxonomy System) to allocate unambiguous didactic interpretation to parts of materials. The dedicated software knowledge repository tool, which was developed to store and process didactic content with the potential to reuse it in various educational contexts, is an essential component of the approach provided. This program allowed single- or multi-topic repositories to be generated with the option of creating distributed repositories.

Abdel-fattah et. al. (2019) presented a development of new model for the production process of e-learning courses to resolve flaws in the National e-learning Center (NELC) model. The suggested model consists of four phases: arbitration, development commencement, e-course review, and e-course activation. The findings demonstrate that in the NELC model, the production process for the ecourse for the proposed model takes an average of 4 weeks instead of 12 months.

Dernl \& Calvo (2011) addressed the usability of instructional design patterns for technology-enhanced learning that can be enhanced as part of an e-learning framework approach by complementing patterns with ready-to-use resources. The researchers proposed two distinct approaches to develop such an e-learning framework: (1) 'Extension' approach offering pattern-based, custom LMS components; and (2) 'Facade' approach allowing existing LMS components to be reused pattern-based. Implementations of both approaches are presented in order to illustrate the effectiveness and advantages of e-learning frameworks. 
Earlier studies have shown many attempts and institutional and personal efforts aimed at designing and developing digital learning objects and then making them accessible to students at different stages of education, but these attempts and efforts are just a start and are not optimally developed because there is no unified paradigm in the design and creation based on educational and technological standards. Therefore, students must be given the opportunity to actively participate in their own learning process by providing various educational resources, which we seek to present during this research by applying an e-learning framework with knowledge repositories to suit all students and give comprehensive, integrated, and continuous teaching and learning results that meet the future needs of the students' community.

\section{Proposed framework}

Digital repositories become more important, especially in different educational stages, as they are used on a wide range, especially in light of technological, educational and digital developments, and this is what prompted the Sultanate of Oman to apply e-learning and digital repositories in the post-basic education stage. The post-basic education stage includes large number of students from different schools, and this was a strong reason to start thinking of making a customized digital repository for them.

In this section, a framework for digital repository will be developed and the study aims to measure its effectiveness after use by post-basic education teachers. As this phase is pivotal in the students' educational journey before joining university education, the framework aims to provide an integrated and interactive content that meets all students' and teachers' needs and makes them easily interact with it. Also, teachers will be able to communicate their experiences in a sequential, accurate, and 
effective manner without any restrictions or difficulties for interaction between them and their students.

Figure 1 describe the steps followed to develop the digital repository for post-basic education in Oman based on international technical and educational standards. This model consists of five stages as follows:

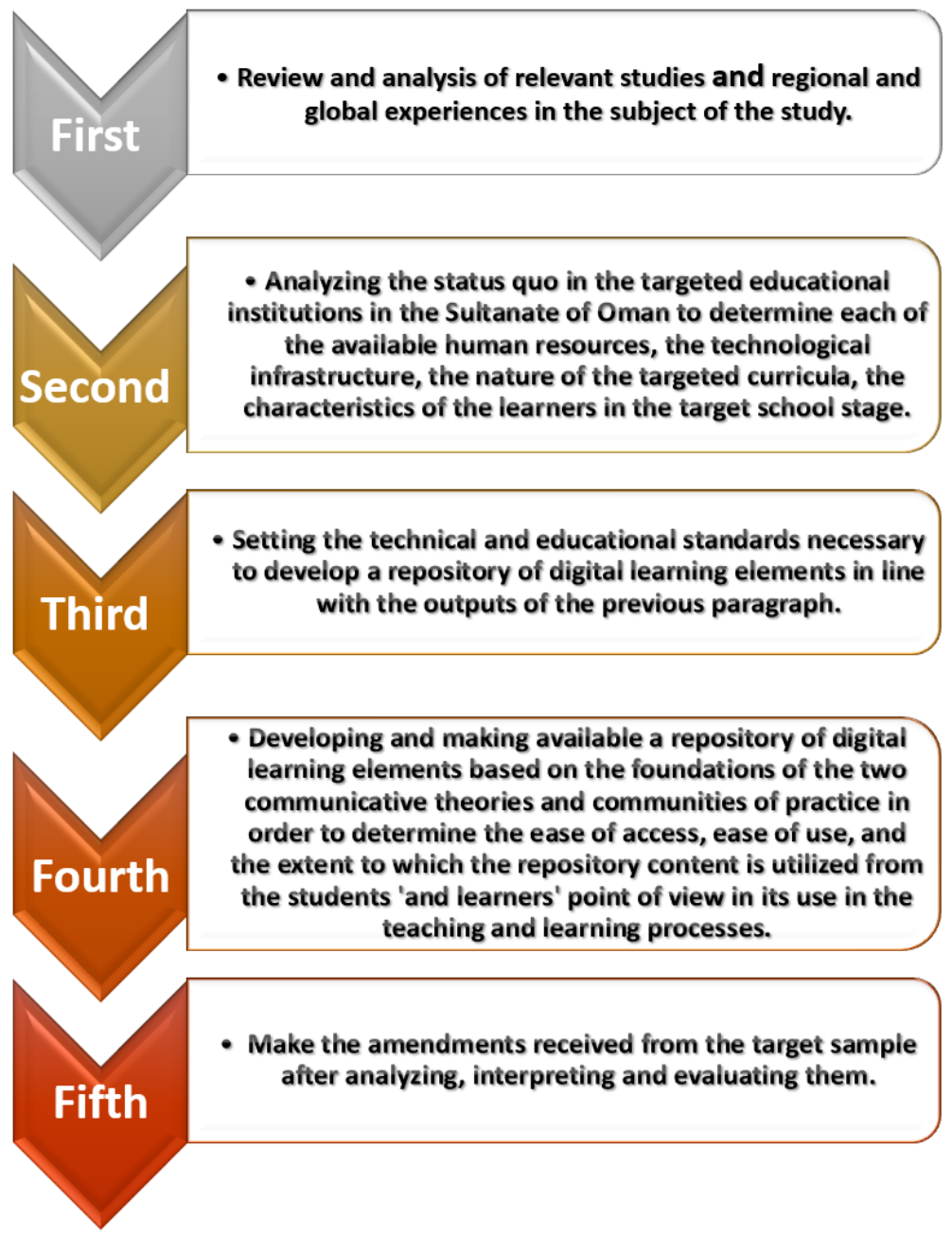

Figure 1 The Proposed model For Learning Objects Repository 


\subsection{Reviewing experiences in digital repositories}

The digital repository of the Library of Alexandria in Egypt: It is one of the most prominent Arab digital repositories, and it has been added to the largest directory of digital repositories, which is the global directory of free access warehouses.

Mansoura University repository in Egypt: Mansoura University warehouse is the first repository for educational units in the Middle East, where its users can access all the educational elements in each of the colleges in the university, and new educational elements can be added to the warehouse, and anything in the content can be modified. Also, through the metadata, all data related to the educational elements are identified. Among the advantages of the system is the possibility of storing and retrieving the educational elements necessary to build electronic courses, and the ability to search for educational units, and the repository constitutes an organized educational site to link other global sources with internally developed learning resources, in addition to that the repository allows the ability to evaluate the content of educational units.

The Saudi Thesaurus for Educational Units: One of the most prominent digital repositories in the Kingdom of Saudi Arabia, and it includes more than a million educational elements, and has had a pioneering role in providing digital content to help students and academics in universities build high-quality digital courses.

Wisconsin Online Resource Center Repository: This electronic repository contains more than 5000 educational objects divided into classes for higher education courses, and these categories include: Business, English language, Health, Professional development, adult education, and technical courses. 
المجلد الخامس (العدد السادس)

2021
المجلة الدولية للمناهج و التربية التكنولوجية

IJCTE

\subsection{Analyzing the status in the targeted educational institutions in Oman:}

Post-basic education in the Sultanate of Oman lasts for two academic years for the eleventh and twelfth grades, and includes basic and optional curricula, taking into account students' desires, preferences and academic abilities, and aims to continue to develop students' basic skills, work skills and career planning in a way that prepares them to be active members in society and be able to take advantage of education, training, and employment opportunities after school education.

Students, educators, and content are the key elements of online learning. The learning experience is mainly influenced by students' contact with material, other students, and teachers. Students are expected to possess high levels of digital literacy in order to participate in interactions effectively, to be self-efficient and properly encouraged to participate in learning activities productively. Similarly, the attitude of educators towards the use of technology and their levels of digital literacy plays a significant role in influencing the overall learning experience. (Castro, 2019)

Other aspects, such as academic support, institutional adoption, and course design, play an important role in moderating the final learning environment and the achievement of learning goals, in addition to the role of students, educators and material. Important features of course design that shape learning experience are flexibility, personalization, forms of assessment, use of small group learning and designed interactions, and soundness of adopted mix of pedagogies, technologies, and media. Similarly, the quality of technical infrastructure, support for academic personnel and the role of academic management, the level of collaboration between stakeholders, and government support and policy creation are factors related to the level of institutional acceptance of online learning. Finally, for students who do not 
have the necessary levels of literacy and self-efficacy, academic support for students, including technical and financial support, is especially important. (Castro, 2019)

\subsection{Setting the technical and educational standards necessary to develop a digital repository}

There are five important aspects to consider when starting e-learning and knowledge repository project for the Sultanate of Oman. ( Kutay, 2014)

\section{- Software}

It is important to determine the best tools for the project especially with e-learning projects. Determine all the tools you need to develop the project, which help in developing educational content in an attractive and easy way. Identify other utilities programs such as graphic editing tool, audio recording program, video editing application and some popular programs.

\section{- Hardware}

Hardware is a critical piece of any e-learning project. It's crucial that your computer meets the technical specifications of the e-learning tools you select. Successful elearning authors often use a quality microphone to record narration, a video camera for videography, and a digital camera to take photos.

\section{- Experts in e-learning}

When you're developing an e-learning course, you often need to rely on the knowledge and expertise of others, particularly, your subject matter experts (SMEs). You might need to interview them to extract information or have them review storyboards. 
المجلد الخامس (العدد السادس)

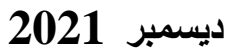

المجلة الدولية للمناهج والتربية التكنولوجية

IJCTE

\section{- Project Resources}

Identify all the resources ahead of time and estimate how long it will need in the list of e-learning requirements. A successful project is often the result of collaboration between many people and departments. Identify any resources need to successfully develop and publish the content: the graphic design department (to create icons or custom graphics), the marketing department (to get photos, logos, and other assets), the technical department (to get your course online and access the learning management system), and the quality assurance department (to test and review the final product).

\section{- Assets}

It's hard to identify exactly which assets needed until we start to develop the storyboard so, set of character photos, some videos, and sound effects in the education contents, include them in the e-learning requirements list to be prepared for all phases of development and won't get stuck scrambling for assets and resources at the last minute.

\subsection{Developing and making available a repository}

Developing and making available a repository of digital learning elements based on the educational and technical standards in order to determine the ease of access, ease of use, and the extent to which the repository content is utilized from the students 'and learners' point of view in its use in the teaching and learning processes.

\subsection{Making the amendments received from the target sample after analyzing}

The amendments received from the target sample after analyzing, interpreting and evaluating them were applied. 
This step will be shown more specifically in the next section which evaluates the digital repository of the interactive e-learning content after implementing it on the post-basic education students in Oman then measure the effectiveness of it on the students and teachers.

Finally, the researchers were able to develop a digital learning object generator as shown in the following figure 2 :

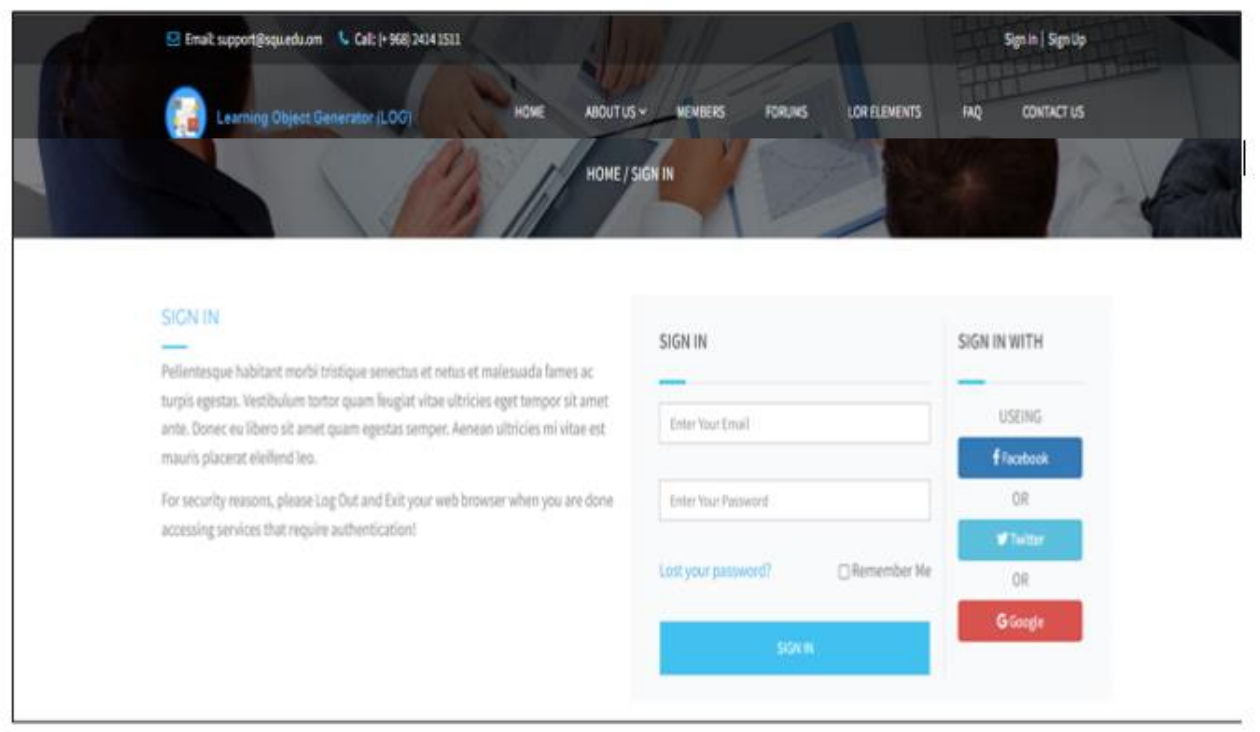

Figure 2 The main interface for the Digital Repository

\section{Methodology}

\subsection{Participants}

The current study employed a descriptive method to validate the developed digital repository so that teachers in Omani schools may quickly have access to vast amount of learning objects related to the curriculum they are teaching. To accomplish this, 
المجلد الخامس (العدد السادس)

ديسمبر 2021
المجلة الدولية للمناهج و التربية التكنولوجية

IJCTE

one hundred teachers were chosen randomly to assess their experience with the developed repository.

\subsection{Research tool}

A questionnaire was developed by the researchers to collect information about the ease of use, accessibility, and effectiveness of the developed digital repository from teachers' perspectives after using the repository. The questionnaire was created using five-point Likert scales and comprised 17 items. Experts in the filed were consulted to determine the validity of the questionnaire. To confirm its reliability, the survey was piloted on 15 teachers with varying years of experience. The scale's Cronbach alpha coefficient was determined to be (0.79), indicating that it is reliable.

\section{Results and Discussion}

A questionnaire was conducted for a random sample of one hundred teachers in the post-basic education stage to measure the ease of use, accessibility, and effectiveness of the digital repository and the extent of its reception and satisfaction from the teachers' point of view.

Table 1 Teachers' prespectives about the developed digital repository 
Developing A Digital Repository Based on Educational and Technical Standards to Provide Interactive E-Learning Content for Post-Basic Education Students in Oman

Dr. Walid Aboraya, Dr. Nader Shemy, Dr. Sameh Said, Dr. Muna Alkalbani, Naglaa Shehata, Baraa Abdelhady

\begin{tabular}{l|c|c|c|c|c|c|c}
\hline \multicolumn{1}{c}{ 2- Disagree } & \multicolumn{3}{c}{ 3-Neutral } & 4- Agree & 5 - Strongly Agree \\
\hline \multicolumn{1}{c|}{ Statement } & SD & D & N & A & SA & $\begin{array}{c}\text { Mea } \\
\text { n }\end{array}$ & STDV \\
\hline $\begin{array}{l}\text { It is easy to search for the } \\
\text { needed learning objects. }\end{array}$ & $2 \%$ & $5 \%$ & $3 \%$ & $57 \%$ & $33 \%$ & 4.38 & 0.91 \\
\hline $\begin{array}{l}\text { I can easily view the required } \\
\text { learning objects online. }\end{array}$ & $1 \%$ & $2 \%$ & $2 \%$ & $50 \%$ & $45 \%$ & 4.41 & 0.72 \\
\hline $\begin{array}{l}\text { The repository will be useful for } \\
\text { students }\end{array}$ & $5 \%$ & $2 \%$ & $3 \%$ & $58 \%$ & $32 \%$ & 4.36 & 1.01 \\
\hline $\begin{array}{l}\text { I think that using the repository } \\
\text { will enhance my teaching. }\end{array}$ & $7 \%$ & $3 \%$ & $5 \%$ & $60 \%$ & $25 \%$ & 4.28 & 1.15 \\
\hline $\begin{array}{l}\text { I think that the repository will } \\
\text { solve many teaching and }\end{array}$ & $11 \%$ & $2 \%$ & $2 \%$ & $62 \%$ & $23 \%$ & 4.23 & 1.29 \\
\begin{tabular}{l} 
learning problems. \\
\hline $\begin{array}{l}\text { I can easily rate the learning } \\
\text { objects and benefit from other } \\
\text { ratings. }\end{array}$
\end{tabular} & $4 \%$ & $5 \%$ & $1 \%$ & $66 \%$ & $24 \%$ & 4.43 & 1.02 \\
\hline $\begin{array}{l}\text { There are various display } \\
\text { options to the results that meet } \\
\text { different needs }\end{array}$ & $2 \%$ & $8 \%$ & $5 \%$ & $55 \%$ & $30 \%$ & 4.28 & 1.01 \\
\hline $\begin{array}{l}\text { It is easy to edit learning objects } \\
\text { objects to the repository }\end{array}$ & $6 \%$ & $3 \%$ & $1 \%$ & $48 \%$ & $42 \%$ & 4.23 & 1.05 \\
\hline
\end{tabular}


المجلد الخامس (العدد السادس)

2021
المجلة الدولية للمناهج والتربية التكنولوجية

IJCTE

\begin{tabular}{l|c|c|c|c|c|c|c}
\hline $\begin{array}{l}\text { There are many useful searching } \\
\text { options available }\end{array}$ & $7 \%$ & $3 \%$ & $5 \%$ & $51 \%$ & $34 \%$ & 4.19 & 1.13 \\
\hline $\begin{array}{l}\text { I feel that the interface is user- } \\
\text { friendly }\end{array}$ & $2 \%$ & $1 \%$ & $1 \%$ & $76 \%$ & $20 \%$ & 4.67 & 0.73 \\
\hline $\begin{array}{l}\text { I can store my own learning } \\
\text { objects and publish them easily }\end{array}$ & $6 \%$ & $4 \%$ & $5 \%$ & $57 \%$ & $28 \%$ & 4.26 & 1.12 \\
\hline $\begin{array}{l}\text { I can create and manage my } \\
\text { own account easily }\end{array}$ & $2 \%$ & $1 \%$ & $2 \%$ & $80 \%$ & $15 \%$ & 4.7 & 0.74 \\
\hline $\begin{array}{l}\text { I can easily download the } \\
\text { required learning objects }\end{array}$ & $4 \%$ & $1 \%$ & $5 \%$ & $66 \%$ & $24 \%$ & 4.47 & 0.94 \\
\hline $\begin{array}{l}\text { Teachers can easily share good } \\
\text { practices }\end{array}$ & $11 \%$ & $8 \%$ & 12 & $44 \%$ & $25 \%$ & 3.83 & 1.36 \\
\hline $\begin{array}{l}\text { There is a good accessible space } \\
\text { for communication among } \\
\text { students }\end{array}$ & $8 \%$ & $11 \%$ & $7 \%$ & $39 \%$ & $35 \%$ & 3.86 & 1.27 \\
\hline $\begin{array}{l}\text { The repository allows good } \\
\text { interaction between teacher and } \\
\text { students }\end{array}$ & $4 \%$ & $6 \%$ & $3 \%$ & $60 \%$ & $27 \%$ & 4.33 & 1.06 \\
\hline
\end{tabular}

Generally, it is clear from the results that most teachers $87 \%$ reported the ease of access, use and effectiveness of the repository. Their responses presented in table 1 shows the following:

$96 \%$ of teachers reported that the interface is user-friendly, $95 \%$ of them stated that they can easily view the required learning objects online, while $90 \%$ agreed about the following: It is easy to search for the needed learning objects, the repository will 
be useful for students, they can easily rate the learning objects and benefit from other ratings, it is easy to edit learning objects in the repository, and they can easily download the required learning objects.

Also, $87 \%$ of the teachers reported that the repository allows good interaction between teacher and students, and $85 \%$ of them agreed about the following: using the repository will enhance their teaching, the repository will solve many teaching and learning problems, there are various display options for the results that meet different needs, there are many useful searching options available, and they can store their own learning objects and publish them easily. And $80 \%$ of them agreed that they can easily upload their learning objects to the repository.

Moreover, $74 \%$ of the teachers reported that there is a good accessible space for communication among students, and finally $69 \%$ reported that teachers can easily share good practices. Although the later got high consensus between teachers, it came in the least rank as the teachers could not practice communication together in the trial version of the repository.

The digital repository has achieved great success and achieved the following:

1. The research project contributed to building a model for digital learning organisms in light of global educational and technical standards consistent with the teaching and learning environment in the Sultanate of Oman, and responding to the actual needs of that environment, and accurately reflecting the nature of the educational content at that educational stage, the characteristics of the learners in the Sultanate, and the structure specifications of Technological infrastructure in the Sultanate. 
المجلد الخامس (العدد السادس)

2021
المجلة الدولية للمناهج و التربية التكنولوجية

IJCTE

2. Create and provide real opportunities for international, regional and local partnerships with governmental and private institutions related to the nature of education and learning in the Sultanate of Oman.

3. Striving towards maximizing the benefit from the Omani cadres in the field of designing and developing interactive electronic content and participating with tangible and valuable contributions to the Omani education community.

4. Establishing the concept of free access to educational digital content (digital learning objects) through an Omani educational platform based on standards and principles consistent with the nature and needs of the education community in the Sultanate.

\section{Conclusion and Future Work}

Digital repositories contain a lot of useful information and elements that help in achieving educational goals. These repositories also contain many digital learning elements, which in turn provide a complete learning environment in which it is easy to reuse these elements in different educational situations according to the requirements of each educational case.

This research presented a framework for a digital repository based on the educational and technical standards, in order to provide interactive e-learning content for postbasic education students in educational institutions, especially in the Sultanate of Oman. The implementation of this work aimed to contribute to the development and updating of the educational content of this important educational stage based on a comprehensive review and analysis of relevant regional and global experiences. The study was developed in light of international technical and educational standards and the capabilities of the Omani education community. The model was applied to the 
Sultanate of Oman and a questionnaire was conducted for the teachers' opinions about the repository the results showed that digital repository make them easily available, and the possibility of developing them at any time from one form to another to keep pace with the rapid development of knowledge, and contribute to meeting the individual needs of learners with different preferences, attitudes, experiences, motivations and levels of study. Providing free access to educational digital content (digital learning objects) through an Omani educational platform available to all members of the education community in the Sultanate. We seek in future work to provide interactive electronic content for students with special needs that suit all types of disabilities.

\section{Acknowledgements}

The research leading to these results has received funding from the Research Council (TRC) of the Sultanate of Oman under the Block Funding Program. TRC Block Funding Agreement No [BFP/RGP/EHR/18/156]. 


\section{References}

Abdel-Fattah, M. A., EMAM, O. E., \& Abdel-Hady, B. A. (2019). Developing Production Process of e-learning Courses: A four Phase Model. International Journal of Applied Engineering Research, 14(10), 2347-2358.

Alanazi, A., Abbod, M., \& Ullah, A. (2014, November). Intelligent e-learning repository system for sharing learning resources. In 2014 International Conference on Web and Open Access to Learning (ICWOAL) (pp. 1-5). IEEE.

Alkhalaf, S., Drew, S., \& Alhussain, T. (2012). Assessing the impact of elearning systems on learners: A survey study in the KSA. ProcediaSocial and Behavioral Sciences, 47, 98-104.

Andersson, A. (2008). Seven major challenges for e-learning in developing countries: Case study eBIT, Sri Lanka. International journal of education and development using ICT, 4(3), 45-62.

Bogucki, J. (2021). Deploying and Maintaining a Repository in the Cloud. Library Technology Reports, 57(5), 21.

Cakiroglu, U., Baki, A., \& Akkan, Y. (2012). The Effects of Using Learning Objects in Two Different Settings. Turkish Online Journal of Educational Technology-TOJET, 11(1), 181-191.

Castro, M. D. B., \& Tumibay, G. M. (2021). A literature review: efficacy of online learning courses for higher education institution using metaanalysis. Education and Information Technologies, 26(2), 1367-1385. 
Derntl, M., \& Calvo, R. A. (2011). E-learning frameworks: facilitating the implementation of educational design patterns. International Journal of Technology Enhanced Learning, 3(3), 284-296.

Esther Akpovi. (2019). Learning Infrastructure, https://medium.com/@estherakpovi/transformation-of-education-by-buildinglearning-infrastructures-c6918f7ec388. [accessed Dec 27,2020 ].

Kamba, M. (2009). Problems, challenges and benefits of implementing elearning in Nigerian universities: An empirical study. International Journal of Emerging Technologies in Learning (iJET), 4(1), 66-69.

Kutay, S. (2014). Advancing digital repository services for faculty primary research assets: An exploratory study. The Journal of academic librarianship, 40(6), 642-649.

Morales, V. T., Mendez, N. D. D., \& Rojas, L. F. L. (2017, October). Towards a model of adaptive and accessible repositories of digital educational resources: FROAC case. In 2017 Twelfth Latin American Conference on Learning Technologies (LACLO) (pp. 1-5). IEEE.

Nyakurerwa, A. T. (2021). Institutional Repository as a Knowledge Management Tool for the Enhancement of Library Visibility in the 21st Century: A Case of Midlands State University. In Handbook of Research on Information and Records Management in the Fourth Industrial Revolution (pp. 81-93). IGI Global.

Ozdemir, O., \& Bonk, C. J. (2017). Turkish teachers' awareness and perceptions of open educational resources. Journal of Learning for Development, 4(3), 307-321. 
المجلد الخامس (العدد السادس)

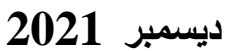

المجلة الدولية للمناهج و التربية التكنولوجية

IJCTE

Samsuri, N. N., Nadzri, F. A., \& Rom, K. B. M. (2014). A study on the student's perspective on the effectiveness of using e-learning. ProcediaSocial and Behavioral Sciences, 123, 139-144.

Sek, Y. W., Law, C. Y., \& Lau, S. H. (2012). The effectiveness of learning objects as alternative pedagogical tool in laboratory engineering education. International Journal of e-Education, e-Business, eManagement and e-Learning, 2(2), 145.

Starzyńska, B., \& Klembalska, A. (2021). A Digital Repository of Science Assets as a Tool for Knowledge Transfer to Manufacturing Enterprises. Management and Production Engineering Review, 12.

Turel, Y. K., \& Gürol, M. (2011). Comprehensive evaluation of learning objects-enriched instructional environments in science classes. Contemporary Educational Technology, 2(4), 264-281.

Vasilyeva, E., Pechenizkiy, M., \& Puuronen, S. (2005). Knowledge management challenges in web-based adaptive e-learning systems. In Proceedings of 5th International Conference on Knowledge Management (pp. 112-119).

Zervas, P., Tsourlidaki, E., Cao, Y., Sotiriou, S., Sampson, D. G., \& Faltin, N. (2016). A study on the use of a metadata schema for characterizing school education STEM lessons plans by STEM teachers. Journal of Computing in Higher Education, 28(3), 389-405. 